\title{
SIRT3 wt Allele
}

National Cancer Institute

\section{Source}

National Cancer Institute. SIRT3 wt Allele. NCI Thesaurus. Code C95590.

Human SIRT 3 wild-type allele is located in the vicinity of $11 \mathrm{p} 15.5$ and is approximately 21

$\mathrm{kb}$ in length. This allele, which encodes NAD-dependent deacetylase sirtuin-3,

mitochondrial protein, is involved in the modulation of protein acetylation. 